\title{
Performance evaluation of the point-of-care SAMBA II SARS-CoV-2 Test for
}

4 Sonny M Assennato ${ }^{a^{*}}$, Allyson V Ritchie ${ }^{a^{*}}$, Cesar Nadala $^{b}$, Neha Goel $^{a}$, Hongyi

5 Zhang ${ }^{c}$, Rawlings Datir ${ }^{d}$, Ravindra K Gupta ${ }^{\mathrm{e}, \mathrm{f}}$, Martin D Curran ${ }^{\text {***}}$, Helen H Lee ${ }^{\mathrm{a}, \mathrm{b} * *} \#$

$7 \quad$ *Assennato and Ritchie contributed equally, author order was decided alphabetically

$8 \quad{ }^{* *}$ Curran and Lee contributed equally

9

10 a. Diagnostics for the Real World EU Ltd., Chesterford Research Park, Great

11 Chesterford, UK

12 b. Diagnostics for the Real World Ltd., San Jose, USA

13 c. Clinical Microbiology and Public Health Laboratory, PHE Cambridge,

14 Addenbrooke's Hospital, Cambridge, UK

15 d. Division of Infection and Immunity, University College London, London, UK

e. Department of Medicine, University of Cambridge, Cambridge, UK

f. Africa Health Research Institute, Durban, South Africa

Running Title: SAMBA II SARS-CoV-2 analytical and clinical evaluation

Key words: SAMBA II, SARS-CoV-2, point-of-care, COVID-19 
medRxiv preprint doi: https://doi.org/10.1101/2020.05.24.20100990; this version posted June 9, 2020. The copyright holder for this preprint (which was not certified by peer review) is the author/funder, who has granted medRxiv a license to display the preprint in perpetuity.

27 Abstract

28 Nucleic acid amplification for the detection of SARS-CoV-2 RNA in respiratory 29 samples is the standard method for diagnosis. These tests are centralised and 30 therefore turnaround times can be 2-5 days. Point-of-care testing with rapid 31 turnaround times would allow more effective triage in settings where patient management and infection control decisions need to be made rapidly. Inclusivity and specificity of the SAMBA II SARS-CoV-2 assay was determined by in silico analyses of the primers and probes. Analytical and clinical sensitivity and specificity of the SAMBA II SARS-CoV-2 Test was evaluated for analytical sensitivity and specificity. Clinical performance was evaluated in residual clinical samples compared to the Public Health England reference tests.

The limit of detection of the SAMBA II SARS-CoV-2 Test is $250 \mathrm{cp} / \mathrm{mL}$ and is specific for detection of 2 regions of the SARS-CoV-2 genome. The clinical sensitivity was evaluated in 172 clinical samples provided by the Clinical Microbiology and Public Health Laboratory, Addenbrooke's Hospital, Cambridge (CMPHL), which showed a sensitivity of $98.9 \%$ (95\% Cl 94.03-99.97\%), specificity of 100\% (95\% Cl 95.55-100\%), PPV of $100 \%$ and NPV of $98.78 \%(92.02-99.82 \%)$ compared to testing by CMPHLSAMBA detected 3 positive samples that were initially negative by PHE Test. The data shows that the SAMBA II SARS-CoV-2 Test performs equivalently to the centralised testing methods with a much quicker turnaround time. Point of care testing, such as SAMBA, should enable rapid patient management and effective implementation of infection control measures. 
medRxiv preprint doi: https://doi.org/10.1101/2020.05.24.20100990; this version posted June 9, 2020. The copyright holder for this preprint (which was not certified by peer review) is the author/funder, who has granted medRxiv a license to display the preprint in perpetuity.

Introduction

The SARS-CoV-2 was first reported in Wuhan, China, in early December 2019 and is

the causative agent of coronavirus disease 19 (COVID-19) [1]. It has since spread to over 188 countries/regions around the world [2], causing 317,234 deaths [3]. It was declared a pandemic by the World Health Organisation on the 11th of March 2020 [4]. In Europe, the country with the highest number of deaths is UK, which as of the $17^{\text {th }}$ of May has had 243,694 lab-confirmed cases and 34,636 deaths in all settings [5].

Nucleic acid testing is essential for early diagnosis of SARS-CoV-2 infection as antibody response is often not detected until 7-10 post onset of symptoms [6]. Upper respiratory tract (URT) specimens such as nose and throat swabs generally have high SARS-CoV-2 viral loads upon symptom onset [7]. The standard diagnostic test for SARS-CoV-2 in the UK is done by real-time RT-PCR of the RdRp gene [8], from a combined throat and nose swab sample. The UK has dramatically scaled up testing from 5,000 tests per day in March 2020 to 100,000 tests per day by the end of April. Although this test has good accuracy, the samples must be transported to centralized testing laboratories and batched for processing, which leads to turnaround times of around 48 hours or more. This means treatment of severely ill patients may be suboptimal when other causative pathogens are in the differential diagnosis and those requiring admission or triage with possible COVID-19 maybe unnecessarily isolated or inappropriately cohorted in a COVID-19 ward. This causes obvious bottlenecks in addition to the sheer number of samples that require processing; at present hospital and regional laboratories are at full capacity and a rapid point of care (POC) testing is required.

75 The SAMBA II nucleic acid testing system was originally designed for HIV testing in 
medRxiv preprint doi: https://doi.org/10.1101/2020.05.24.20100990; this version posted June 9, 2020. The copyright holder for this preprint (which was not certified by peer review) is the author/funder, who has granted medRxiv a license to display the preprint in perpetuity.

POC and resource-limited settings, with CE-marked products for early infant diagnosis

SAMBA II SARS-CoV-2 Test system has now been developed to specifically detect the presence of the novel coronavirus, SARS-CoV-2, in nose and throat swab samples run on the SAMBA II instrument. Test results are available in approximately 1.5 hours.

We have here assessed the analytical and clinical performance of the SAMBA II SARS-CoV-2 Test using panels and clinical samples.

Materials and Methods

\section{SAMBA sample preparation, amplification, and detection}

For the SAMBA II system, sample preparation, amplification, and detection as well as reading and interpretation of the results are fully automated. The test is carried out in the SAMBA II Assay Module under the control of the SAMBA II Tablet Module as previously described for HIV [9-12], according to the manufacturer's instructions for use. Nose and throat swab samples are preferably resuspended in $2 \mathrm{~mL}$ of SAMBA SCoV buffer but the system can be used with viral transport medium (VTM) if the sample is diluted 1:2 with SCoV buffer prior to processing. The input volume for the SAMBA test is $300 \mu \mathrm{l}$ of which $250 \mu \mathrm{l}$ is used by the SAMBA II machine as input into the sample preparation. The SAMBA II SARS-CoV-2 Test specifically amplifies and detects two regions of the SARS-CoV-2 genome in the ORF1ab (region 1) and nucleocapsid protein (region 2), reported as two distinct lines on the test strip. A third line on the test strip, the internal control, is present to control for false negatives caused by instrument/reagent problems or inhibition. The presence of one or both test

100 lines indicates a positive result. The presence of just the internal control line indicates 
medRxiv preprint doi: https://doi.org/10.1101/2020.05.24.20100990; this version posted June 9, 2020. The copyright holder for this preprint (which was not certified by peer review) is the author/funder, who has granted medRxiv a license to display the preprint in perpetuity.

a negative result.

\section{Virus inactivation in SAMBA SCoV buffer}

103 SAMBA SCoV buffer, containing Triton $\times 100$, is provided with the SAMBA II SARS-

104 CoV-2 Test for sample collection of the nose and throat swabs. Single round of VSV-

105 G pseudotyped lentiviruses were produced by transfecting HEK-293T cells in a 3-

106 plasmid transfection system (HIV Gag-pol expresser under a CMV promoter,

107 luciferase genome reporter and VSV-g envelope) as previously described [14]. Virus

108 supernatant was harvested after 24 hours and filtered. Fifty (50) $\mu \mathrm{L}$

109 of pseudovirus preparation was added to increasing dilutions of SAMBA SCoV Buffer

110 in duplicates and incubated at room temperature for 5 minutes. $100 \mu \mathrm{L}$ of the virus-

111 reagent prep was then used to infect $1.0 \times 10^{6} \mathrm{TZMbl}$ target cells per well in a 96-well

112 plate and incubated at $37^{\circ} \mathrm{C}, 5 \% \mathrm{CO}_{2}$. Forty-eight (48) hours post-infection, luciferase

113 expression was measured using SteadyGlo and a Glomax Luminometer (both

114 Promega).

115

116 In silico inclusivity analysis

117 The SAMBA-SARS-CoV-2 primers and probes for Orf1ab and $\mathrm{N}$ regions were

118 individually evaluated using in-silico analysis with respect to 157 SARS-CoV-2

119 sequences in the NCBI database.

\section{$121 \quad$ In silico specificity analysis}

122 In silico analysis for possible cross-reactions with related human Coronaviruses

123 (Human coronavirus 229E, Human coronavirus OC43, Human coronavirus HKU1,

124 Human coronavirus NL63, SARS-coronavirus and MERS-coronavirus) was conducted 
medRxiv preprint doi: https://doi.org/10.1101/2020.05.24.20100990; this version posted June 9, 2020. The copyright holder for this preprint (which was not certified by peer review) is the author/funder, who has granted medRxiv a license to display the preprint in perpetuity.

by mapping primers in the SAMBA II SARS-CoV-2 Test individually to the sequences downloaded from the NCBI database.

127 An in silico analysis for possible cross-reactions with other high-priority organisms was conducted by carrying out a blastn search for each of the SAMBA primers and probes against $\mathrm{NCBI}$ databases and retrieving all sequences with homologies $>80 \%$.

\section{Panels and samples}

132 Panel members for determination of the limit of detection (LOD) were prepared by

133 making serial dilutions of SARS-CoV-2 RNA from strain 2019-nCoV/Italy-INMI1 from

134 EVAg (code number: 008N-03894) in pooled negative combined nose and throat swab samples to target concentrations of $750,500,250,200,150$ and 100 copies/mL.

137 A Coronavirus RNA specificity panel containing hCoV-NL63, hCoV-229E, hCoV-

138 OC43, MERS-CoV and SARS-CoV HKU339849 were sourced from EVAg (code

139 number $011 \mathrm{~N}-03868)$. RNA samples from this panel were tested at $>100,000 \mathrm{cp} /$ test

140 in the SAMBA II test to determine specificity against other human Coronaviruses.

\section{Contrived clinical samples}

143 Combined nose and throat swabs were collected from 35 presumed negative 144 individuals using FLOQSwabs (Copan, Italy) and SAMBA SCoV buffer. Thirty 145 contrived positive clinical samples were prepared by spiking known concentrations of 146 SARS-CoV-2 RNA strain 2019-nCoV/Italy-INMI1 (EVAg, Italy) into individual negative 147 specimens to produce final concentrations of $1 x \operatorname{LoD}(n=3), 2 x \operatorname{LoD}(n=17), 3 x \operatorname{LoD}$ $(n=5), 5 x \operatorname{LoD}(n=3)$ and 100x LoD $(n=2)$. 
medRxiv preprint doi: https://doi.org/10.1101/2020.05.24.20100990; this version posted June 9, 2020. The copyright holder for this preprint (which was not certified by peer review) is the author/funder, who has granted medRxiv a license to display the preprint in perpetuity.

\section{Clinical evaluation}

151 The clinical performance of the SAMBA II SARS-CoV-2 Test was further evaluated

152 retrospectively with 172 residual blinded combined nose and throat swab samples

153 from CMPHL Cambridge laboratory. These residual samples were from symptomatic

154 individuals with suspected Covid-19 from around the East of England region sent for routine laboratory diagnosis and provided as VTM diluted 1:2 with SAMBA SCoV buffer. In total 172 samples were tested by the SAMBA II SARS-CoV-2 Test and results were compared to the Cambridge RdRp gene (Wuhan) assay on the Rotor gene $Q$ real-time PCR assay routinely used by CMPHL based on the publication by

159 Sridhar et al., 2020 [15]. Results are expressed as positive or negative with a Ct cut 160 off of 36 for positive results. Samples were also tested with the PHE Colindale 161 (Reference Laboratory) assay, based on the publication by Corman et al, 2020 [8], which amplifies a different region of the RdRp gene.

163 For LOD, we used SARS-CoV-2 RNA quantified in $\mathrm{cp} / \mathrm{mL}$ but in the clinical samples,

164 SAMBA II results were compared to real-time PCR results expressed as Ct number 165 (number of cycles). By systematically testing serial dilutions of samples calibrated in $\mathrm{cp} / \mathrm{mL}$ by the PHE test a correspondence curve was drawn showing for instance that 25 Ct corresponded to $100,000 \mathrm{cp} / \mathrm{mL}$ and $30 \mathrm{Ct}$ to $1,000 \mathrm{cp} / \mathrm{mL}$. The curve obtained is added as supplementary information.

\section{Research Ethics}

171 Surplus samples obtained from patients known to be symptomatic for COVID-19 and

172 submitted to the CMPHL for routine testing were retrieved before being discarded.

173 These samples were rendered anonymous and provided blinded for the purpose of 174 test validation. Public Health England and NHS Research Ethics Committee have 
medRxiv preprint doi: https://doi.org/10.1101/2020.05.24.20100990; this version posted June 9, 2020. The copyright holder for this preprint (which was not certified by peer review) is the author/funder, who has granted medRxiv a license to display the preprint in perpetuity.

permitted the use of residual samples in this manner, strictly for the purpose of diagnostic assay validation [16]. The evaluation was carried out in accordance with

177 The Use of Human Organs and Tissue act [17].

179 Results

180 Viral inactivation by SAMBA SCoV collection buffer

181 Due to the highly infectious nature of SARS-CoV-2, a proprietary buffer which has a 182 low $\mathrm{pH}$ and a strong detergent was developed for the SAMBA SARS-CoV-2 Test for 183 sample collection. The ability of the SAMBA SCoV Buffer to inactivate pseudoviruses

184 was assessed by incubating pseudoviruses with increasing dilutions of 185 SAMBA SCoV Buffer in duplicates at room temperature for 5 minutes. Forty-eight (48) 186 hours post-infection, luciferase expression was measured. Figure 1 shows the plot of $187 \log _{10}$ relative light units (RLU) of luciferase expression vs concentration of 188 SAMBA SCoV Buffer containing Triton X100. Results show that luciferase activity was 189 insignificant up to $1: 128$ dilution of the SAMBA SCoV Buffer, indicating that 190 the pseudovirus was inactivated after 5-minute exposure at room temperature (Figure 191 1). For the SAMBA II Test, a 10-minute soaking of the swab in the 192 SAMBA SCoV Buffer is recommended.

\section{Limit of detection}

195 The limit of detection (LOD) of the SAMBA II SARS-CoV-2 Test was determined using serial dilutions of SARS-CoV-2 RNA in pooled negative combined nose and throat

197 swab samples. The initial LOD was determined by testing 6 levels at target 198 concentrations of $750,500,250,200,150$ and 100 copies $/ \mathrm{mL}$. Each panel member 199 was tested in replicates of 3 (Table 1). The final LOD was confirmed by testing 250 
medRxiv preprint doi: https://doi.org/10.1101/2020.05.24.20100990; this version posted June 9, 2020. The copyright holder for this preprint (which was not certified by peer review) is the author/funder, who has granted medRxiv a license to display the preprint in perpetuity.

copies $/ \mathrm{mL}$ in replicates of 20 , of which all were detected. The results are summarized

201 in Table 1. Therefore, the claimed LOD of the SAMBA II SARS-CoV-2 Test is 250

$202 \mathrm{cp} / \mathrm{mL}$.

Inclusivity

205 The SAMBA II SARS-CoV-2 Test primers and probes for Target 1 (Orf 1ab) had 100\% match to all but one available SARS-CoV-2 sequence for this region in the NCBI database $(n=157)$. For this one sequence, a single nucleotide mismatch was found that maps to the capture probe with no predicted impact on the assay performance.

209 The primers and probes for Target $2(\mathrm{~N})$ had $100 \%$ identity to all available SARS-CoV2102 sequences for this region in the NCBI database $(n=157)$.

\section{Specificity analysis}

213 In silico analysis for possible cross-reactions with related human coronaviruses

214 (Human coronavirus 229E, Human coronavirus OC43, Human coronavirus HKU1,

215 Human coronavirus NL63, SARS-coronavirus and MERS-coronavirus) concluded that

216 none of the SAMBA primers had $>80 \%$ homology to the organisms listed. In addition

217 to in silico analysis, the SAMBA II SARS-CoV-2 Test was evaluated for specificity by

218 using $>100,000 \mathrm{cp} /$ test of hCoV-NI63, hCoV-229E, hCoV-OC43, MERS-CoV and

219 SARS-CoV RNA as target in the assay. All samples gave negative results in SAMBA

220 showing that both the Orf1ab and $\mathrm{N}$ primers and probes in the SAMBA II SARS-CoV-

2212 were specific.

222 An in silico analysis for possible cross-reactions with other high-priority organisms

223 showed that only one SAMBA probe ( $\mathrm{N}$ region) had greater than $80 \%$ homology $(81 \%)$

224 to one of the high priority organisms (Pneumocystis jirovecii [PJP]). This marginal 
medRxiv preprint doi: https://doi.org/10.1101/2020.05.24.20100990; this version posted June 9, 2020. The copyright holder for this preprint (which was not certified by peer review) is the author/funder, who has granted medRxiv a license to display the preprint in perpetuity.

homology would not impact the performance of the test because the other primers and probes have no homology to $P$. jirovecii. This homology would not be able to compete with $100 \%$ homology of the SARS-CoV-2 amplicon to the capture probe.

\section{Contrived clinical specimens}

Positive $(n=30)$ and negative $(n=35)$ swab samples were contrived from individual nose and throat swab samples collected from 35 individuals and tested with the SAMBA II SARS-CoV-2 Test. Spiked positive samples were tested at 1x LOD $(n=3)$, $2 x \operatorname{LOD}(n=17), 3 x \operatorname{LOD}(n=5), 5 x \operatorname{LOD}(n=3)$ and 100x LOD $(n=2)$ by spiking SARSCoV-2 RNA into individual negative swab samples. All 35 negative samples were negative and all 30 spiked positive samples were positive when tested with the SAMBA II SARS-CoV-2 Test (Table 2). The overall sensitivity was 100\% (95\% Cl: $88.43-100 \%)$ and specificity was $100 \%(95 \% \mathrm{Cl}: 90-100 \%)$.

\section{Clinical evaluation}

The clinical performance of the SAMBA II SARS-CoV-2 Test was further evaluated with 172 combined nose and throat samples from symptomatic individuals provided blinded by CMPHL. The samples were provided in Viral Transport Medium (VTM) diluted 1:2 with SAMBA SCoV buffer. After initial testing there were 87 concordant positives, 81 concordant negatives and 4 discrepant results (3 SAMBA positive and one SAMBA negative) compared with the PHE Colindale reference laboratory test (Table 3). The three SAMBA positive samples were repeat positive by SAMBA and on retest by CMPHL they were found to be borderline positive with high CT values for at least one of the target genes on the Colindale or Cambridge (Wuhan) test (Table 4). The one SAMBA negative sample was negative on repeat by SAMBA but was positive 
medRxiv preprint doi: https://doi.org/10.1101/2020.05.24.20100990; this version posted June 9, 2020. The copyright holder for this preprint (which was not certified by peer review) is the author/funder, who has granted medRxiv a license to display the preprint in perpetuity.

by PHE for RdRp using both the Cambridge (Wuhan) and Colindale assays, with Ct

251 values of 28.87 and 31.18 respectively (Table 4 ). Therefore, there was just 1

252 discrepant sample after retest, a false negative for SAMBA (Table 5). From this data set the SAMBA II SARS-CoV-2 Test has a sensitivity of $98.9 \%(95 \% \mathrm{Cl} 94.03-$ 99.97\%), specificity of $100 \%$ (95\% CI $95.55-100 \%)$, PPV of $100 \%$ and NPV of $98.78 \%$ (92.02-99.82\%) when compared to the PHE reference tests. The one SAMBA false negative gave a high $\mathrm{Ct}$ value on the PHE test (>31), suggesting low viral load, and it was diluted (1:2) for SAMBA testing, which may explain the false-negative result.

\section{Discussion}

260 POC molecular tests for SARS-CoV-2, such as SAMBA II, are required to quickly triage patients as centralised testing can take 2-5 days for results. In addition, POC tests would be extremely useful for non-laboratory residential settings such as prisons, immigration centres, nursing homes and rehabilitative centres. The people living in such facilities tend to be vulnerable populations who are at a higher risk for adverse outcome and for infection due to living in close proximity to others [18] and early identification and implementation of increased infection control measures would reduce spread amongst residents and staff. POC would also be extremely useful in other situations where rapid and accurate results are required e.g organ donation,

269 hospital admissions and emergency surgery. POC molecular tests with rapid 270 turnaround, such as SAMBA II, will be essential not only during high rates of infection but also as the country begins to end the lockdown period and localised outbreaks will need to be managed quickly and efficiently.

273 Our data shows that the SAMBA II SARS-CoV-2 Test is equivalent to centralised 274 testing with excellent sensitivity and specificity. Samples are inactivated in the SAMBA 
medRxiv preprint doi: https://doi.org/10.1101/2020.05.24.20100990; this version posted June 9, 2020. The copyright holder for this preprint (which was not certified by peer review) is the author/funder, who has granted medRxiv a license to display the preprint in perpetuity.

collection buffer and results are available within 86-101 minutes at the POC. High sensitivity and specificity are essential for the appropriate triaging and treatment of

277 incoming patients. The assay has a limit of detection of $250 \mathrm{cp} / \mathrm{mL}$, which is in-line

278 with that claimed by other commercial SARS-CoV-2 tests $[19,20]$. The specificity of 279 the SAMBA SARS-CoV-2 Test in clinical samples was $100 \%$ and the sensitivity was 98.9\% compared to the centralised molecular testing by CMPHL. This data includes 3 positive samples detected by SAMBA that were original negative by centralised testing indicating good sensitivity. Clinical evaluation by Zhen et al [21] comparing the performance of Xpert巴 Xpress SARS-CoV-2 (Cepheid), ePlex® SARS-CoV-

2 (GenMark) and ID NOW ${ }^{\text {TM }}$ COVID-19 (Abbott) showed limit of detection of 100 $\mathrm{cp} / \mathrm{mL}, 1,000 \mathrm{cp} / \mathrm{mL}$ and $10,000 \mathrm{cp} / \mathrm{mL}$ and clinical agreement with the reference standard of $98.3 \%, 91.4 \%$ and $87.7 \%$ respectively. In another study the Xpert system has been shown to have good agreement with the reference test over a wide range of Ct values, including low positives [22,23] with a positive agreement of $98.9 \%$ and negative agreement of $92.0 \%$ compared to Roche cobas [22]. The Abbott ID NOW has been shown to have a positive agreement of $73.9 \%(95 \% \mathrm{Cl}: 63.2-82.3 \%)$ and negative agreement of $100 \%(95 \% \mathrm{Cl}: 92.9-100 \%)$ compared to the lab-based Roche cobas system, with the majority of false negative samples being low viral load $(>30 \mathrm{Ct}$ cycles by Roche cobas) [22]. Abbott have since modified the instructions for use to remove the use of swab in transport medium as samples may become too dilute and 295 affect the sensitivity [24].

296 Potential limitations of this study include that the virus inactivation study was carried

297 out using a constructed pseudovirus rather than a SARS-CoV-2 or other coronavirus 298 due to availability. Also clinical samples were collected in VTM and diluted 1:2 in SCoV 299 buffer rather than collected directly into SCoV buffer, which may affect the sensitivity. 
medRxiv preprint doi: https://doi.org/10.1101/2020.05.24.20100990; this version posted June 9, 2020. The copyright holder for this preprint (which was not certified by peer review) is the author/funder, who has granted medRxiv a license to display the preprint in perpetuity.

Acknowledgements

RKG is funded by Wellcome Senior Fellowship In Clinical Science award no WT108082AIA

\section{References}

1. Huang C, Wang Y, Li X, Ren L, Zhao J, Hu Y, Zhang L, Fan G, Xu J, Gu X, Cheng Z, Yu T, Xia J, Wei Y, Wu W, Xie X, Yin W, Li H, Liu M, Xiao Y, Gao H, Guo L, Xie J, Wang G, Jiang R, Gao Z, Jin Q, Wang J, Cao B. 2020. Clinical features of patients infected with 2019 novel coronavirus in Wuhan, China. Lancet 395(10223):497-506.

2. COVID-19 Dashboard by the Center for Systems Science and Engineering (CSSE) at John Hopkins University (JHU). ArcGIS. John Hopkins University. (Accessed 18 ${ }^{\text {th }}$ May 2020).

3. https://www.worldometers.info/coronavirus/ (Accessed 18

4. World Health Organisation. 2020. WHO Director-General's opening remarks at the media briefing on COVID-19 - 11 March 2020. Available from: https://www.who.int/dg/speeches/detail/who-director-general-s-openingremarks-at-the-media-briefing-on-covid-19---11-march-2020. (Accessed $10^{\text {th }}$ May 2020)

5. https://coronavirus.data.gov.uk (Accessed 18 ${ }^{\text {th }}$ May 2020).

6. Grzelak L, Temman S, Plachais C, Grzelak L, Temmam S, Planchais C, 
medRxiv preprint doi: https://doi.org/10.1101/2020.05.24.20100990; this version posted June 9, 2020. The copyright holder for this preprint (which was not certified by peer review) is the author/funder, who has granted medRxiv a license to display the preprint in perpetuity.

Q, Descamps D, Pourbaix A, Yazdanpanah Y, Tondeur L, Besombes C, CoV-2 serological analysis of COVID-19 hospitalized patients, paucisymptomatic individuals and blood donors. medRxiv https://doi.org/10.1101/2020.04.21.20068858

7. Pan Y, Zhang D, Yang P, Poon LIM, Wang Q. 2020. Viral load of SARS-CoV-2 in clinical samples. The Lancet. 20(4):411-412.

8. Corman, VM, Landt O, Kaiser M, Molenkamp R, Meijer A, Chu DKW, Bleicker T, Brnink S, Schneider J, Schmidt ML, Mulders DGJC, Haagmans BL, van der Veer B, van den Brink S, Wijsman L, Goderski G, Romette J-L, Ellis J, Zambon M, Peirlis M, Goossens H, Reusken C, Koopmans MPG, Drosten C. 2020. Detection of 2019 novel coronavirus (2019-nCoV) by real-time RT-PCR. Euro Surveill, 25(3) https://doi.org/10.2807/1560-7917.ES.2020.25.3.2000045

9. Ritchie AV, Goel N, Sembongi H, Lehga J, Farleigh LE, Edemaga D, Wisniewski CA, Lee HH.(2016. Performance evaluation of the point-of-care SAMBA I and II HIV-1 Qual whole blood tests. J Virol Methods. Nov;237:143149.

10. Ondiek J, Namukaya Z, Mtapuri-Zinyowera S, Balkan S, Elbireer A, Ushiro Lumb I, Kiyaga C, Goel N, Ritchie A, Ncube P, Omuomu K, Ndiege K, Kekitiinwa A, Mangwanya D, Fowler MG, Nadala L, Lee H. 2017. Multicountry validation of SAMBA - A novel molecular point-of-care test for HIV-1 detection in resource-limited setting. J Acquir Immune Defic Syndr. Oct 1;76(2):e52-e57. 
medRxiv preprint doi: https://doi.org/10.1101/2020.05.24.20100990; this version posted June 9, 2020. The copyright holder for this preprint (which was not certified by peer review) is the author/funder, who has granted medRxiv a license to display the preprint in perpetuity.

11. Ritchie AV, Ushiro-Lumb I, Edemaga D, Joshi HA, De Ruiter A, Szumilin E, Jendrulek I, McGuire M, Goel N, Sharma PI, Allain JP, Lee HH. 2014. SAMBA HIV semiquantitative test, a new point-of-care viral-load-monitoring assay for resource-limited settings. J Clin Microbiol. 52(9):3377-83.

12. Goel N, Ritchie AV, Mtapuri-Zinyowera S, Zeh C, Stepchenkova T, Lehga J, De Ruiter A, Farleigh LE, Edemaga D, So R, Sembongi H, Wisniewski C, Nadala L, Schito M, Lee H. 2017. Performance of the SAMBA I and II HIV-1 Semi-Q Tests for viral load monitoring at the point-of-care. J Virol Methods. Jun;224:39-45.

13. Titchmarsh L, Zeh, C, Verpoort T, Allain, J-P and Lee, H.2015. Leukodepletion as a Point-of-Care Method for Monitoring HIV-1 Viral Load in Whole Blood. J. Clin. Microbiol.53(4):1080-1086. length HIV-1 Gag determines protease inhibitor susceptibility within in vitro assays. AIDS. Jul17;24(11):1615-1655.

15. Sridhar S, Forrest S, Kean I, Young J, Scott JB, Maes M, Pereira-Dias J, Parmar S, Routledge M, Rivett L, Dougan G, Weekes M, Curran M, Goodfellow I, Baker S. 2020. A blueprint for the implementation of a validated approach for the detection of SARS-Cov2 in clinical samples in academic facilities. bioRxiv https://doi.org/10.1101/2020.04.14.041319

16. Public Health England. 2017. UK Standards for Microbiology Investigations - Evaluations, validations and verifications of diagnostic tests. Issue no. 5, 16 March 2017

17. UK Legislation. Human Tissue Act. 2004. 
medRxiv preprint doi: https://doi.org/10.1101/2020.05.24.20100990; this version posted June 9, 2020. The copyright holder for this preprint (which was not certified by peer review) is the author/funder, who has granted medRxiv a license to display the preprint in perpetuity.

18. Infection Prevention and Control guidance for Long-Term Care Facilities in the context of COVID-19: World Health Organisation. [updated 21 March 2020]. Available from: https://apps.who.int/iris/handle/10665/331508. (Accessed 11 May 2020).

19.FDA. 2020. Xpert® Xpress SARS-CoV-2 Instructions for Use, April 2020. https://www.fda.gov/media/136314/download (Accessed 10 May 2020).

20.FDA. 2020. Biomerieux ARGENE® SARS-CoV-2 R Gene® Instructions for Use, May 2020. https://www.fda.gov/media/137742/download (Accessed 10 May 2020).

21.Zhen W, Smith E, Manj R, Schron D, Berry GJ. (2020) Clinical Evaluation of Three Sample-To-Answer Platforms for the Detection of SARS-CoV-2. J. Clin.

22. Smithgall MC, Scherberkova' I, Whittier S, Green DA (2020) Comparison of Cepheid Xpert Xpress and Abbott ID Now to Roche cobas for the Rapid Detection of SARS-CoV-2. bioRxiv https://doi.org/10.1101/2020.04.22.055327. 23. Moran A, Beavis KG, Matushek SM, Ciaglia C, Francios N, Tesic V, Love N. 2020. The Detection of SARS-CoV-2 using the Cepheid Xpert Xpress SARSCoV-2 and Roche cobas SARS-CoV-2 Assays. J Clin Microbiol. Apr 17. doi: 10.1128/JCM.00772-2

24. Abbott. 2020. ID NOW COVID-19 Technical Brief and Sample Type Labelling Update. April 2020 
medRxiv preprint doi: https://doi.org/10.1101/2020.05.24.20100990; this version posted June 9, 2020. The copyright holder for this preprint (which was not certified by peer review) is the author/funder, who has granted medRxiv a license to display the preprint in perpetuity.

Figure 1. Viral inactivation as demonstrated by Luminescence from a VSV-G

397 (SCoV Buffer).

398

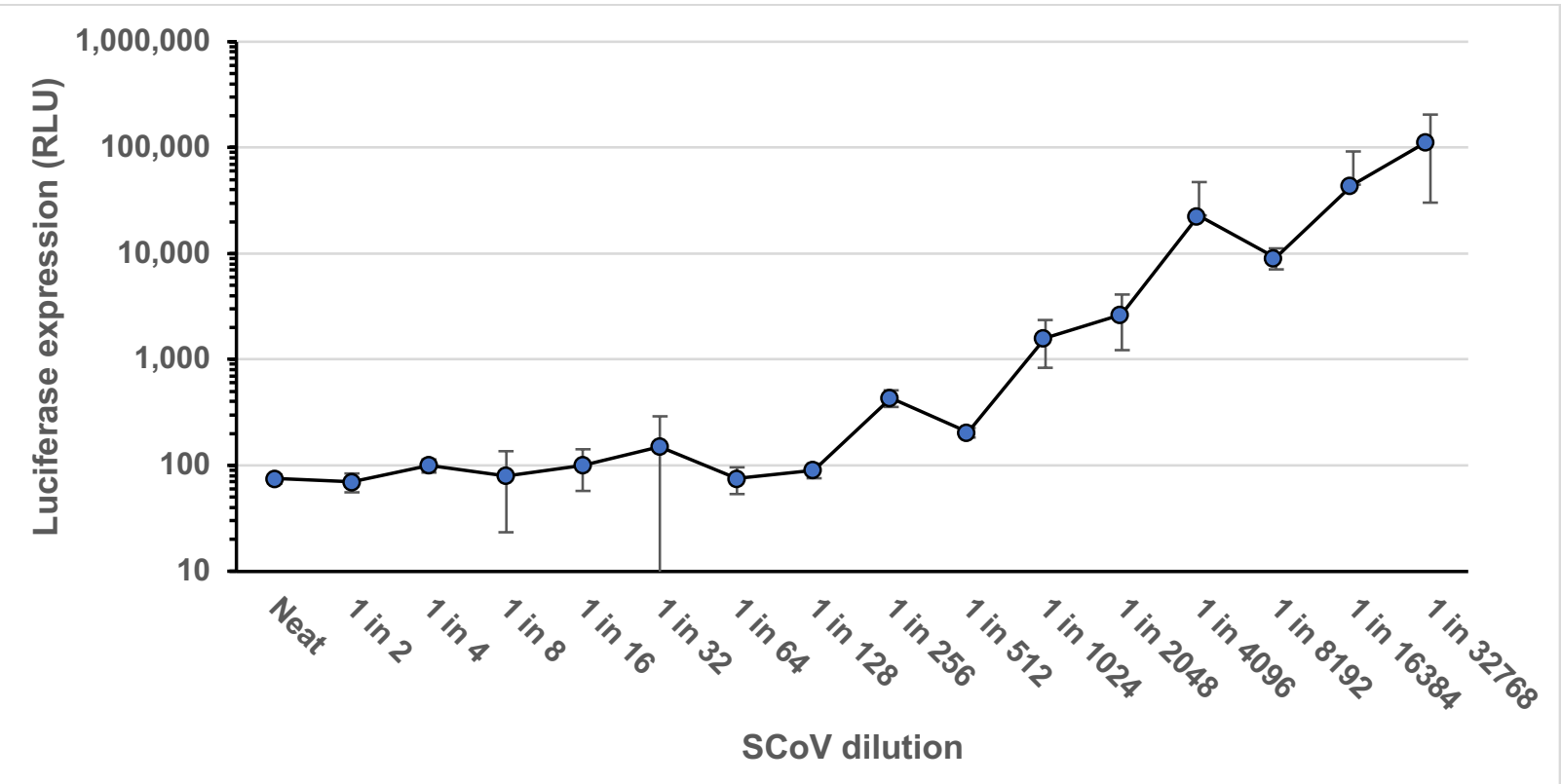

399

400

Table 1. LOD of the SAMBA II SARS-CoV-2 Test

\begin{tabular}{|c|c|c|c|}
\hline $\begin{array}{c}\text { Concentration SARS-CoV-2 } \\
\text { RNA (cp/mL) }\end{array}$ & $\begin{array}{c}\text { Number } \\
\text { tested }\end{array}$ & $\begin{array}{c}\text { Number } \\
\text { positive }\end{array}$ & \% positive \\
\hline 750 & 3 & 3 & 100 \\
\hline 500 & 3 & 3 & 100 \\
\hline $\mathbf{2 5 0}$ & $\mathbf{2 0}$ & $\mathbf{2 0}$ & $\mathbf{1 0 0}$ \\
\hline 200 & 3 & 2 & 66.7 \\
\hline 150 & 3 & 2 & 66.7 \\
\hline 100 & 3 & 0 & 0 \\
\hline
\end{tabular}

402 
medRxiv preprint doi: https://doi.org/10.1101/2020.05.24.20100990; this version posted June 9, 2020. The copyright holder for this preprint (which was not certified by peer review) is the author/funder, who has granted medRxiv a license to display the preprint in perpetuity.

Table 2. Clinical performance in 65 contrived clinical samples

\begin{tabular}{|c|c|c|c|}
\hline $\begin{array}{l}\text { Concentration SARS-CoV-2 RNA } \\
(\mathrm{cp} / \mathrm{mL})\end{array}$ & $\begin{array}{l}\text { Number } \\
\text { tested }\end{array}$ & $\begin{array}{l}\text { Number } \\
\text { positive }\end{array}$ & $\begin{array}{c}\text { \% agreement } \\
(95 \% \mathrm{Cl})\end{array}$ \\
\hline $1-2 x$ LOD & 20 & 20 & $\begin{array}{c}100 \% \\
(86.1-100 \%)\end{array}$ \\
\hline$\geq 3 x$ LOD & 10 & 10 & $\begin{array}{c}100 \% \\
(74.1-100 \%)\end{array}$ \\
\hline Negative & 35 & 0 & $\begin{array}{c}100 \% \\
(91.5-100 \%)\end{array}$ \\
\hline
\end{tabular}

406

\begin{tabular}{cc||cc} 
& & \multicolumn{2}{c}{ PHE reference test } \\
& & POSITIVE & NEGATIVE \\
\hline \hline SAMBA SARS-CoV-2 & POSITIVE & 87 & 3 \\
Test & NEGATIVE & 1 & 81
\end{tabular}

409

410

411

412

413 
medRxiv preprint doi: https://doi.org/10.1101/2020.05.24.20100990; this version posted June 9 , 2020. The copyright holder for this preprint (which was not certified by peer review) is the author/funder, who has granted medRxiv a license to display the preprint in perpetuity.

Table 4. Discrepant analysis of 4 samples

\begin{tabular}{|c|c|c|c|c|c|c|c|}
\hline \multirow{2}{*}{$\begin{array}{c}\text { Sample } \\
\text { ID }\end{array}$} & \multicolumn{2}{|c|}{ SAMBA } & \multicolumn{2}{c|}{$\begin{array}{c}\text { PHE Colindale } \\
\text { assay RdRp }\end{array}$} & \multicolumn{2}{c|}{$\begin{array}{c}\text { PHE Wuhan } \\
\text { Cambridge } \\
\text { assay }\end{array}$} & \multirow{2}{*}{$\begin{array}{c}\text { Final } \\
\text { result }\end{array}$} \\
\cline { 2 - 7 } & $\begin{array}{c}\text { Initial } \\
\text { result }\end{array}$ & $\begin{array}{c}\text { Repeat } \\
\text { result }\end{array}$ & $\begin{array}{c}\text { Initial } \\
(\mathbf{C t})\end{array}$ & $\begin{array}{c}\text { Repeat } \\
\text { (Ct) }\end{array}$ & $\begin{array}{c}\text { RdRp } \\
\text { (Ct) }\end{array}$ & $\begin{array}{c}\text { E } \\
(\mathbf{C t})\end{array}$ & POS \\
\hline $1-25$ & NEG & NEG & $\begin{array}{c}\text { POS } \\
(31.18)\end{array}$ & $\begin{array}{c}\text { Not } \\
\text { tested }\end{array}$ & $\begin{array}{c}\text { POS } \\
(28.87)\end{array}$ & $\begin{array}{c}\text { Not } \\
\text { tested }\end{array}$ & POS \\
\hline $2-17$ & POS & POS & NEG & NEG & NEG & $\begin{array}{c}\text { POS } \\
(34.99)\end{array}$ & POS \\
\hline $2-25$ & POS & POS & $\begin{array}{c}\text { NEG } \\
(36.58)\end{array}$ & $\begin{array}{c}\text { POS } \\
(33.62)\end{array}$ & NEG & NEG & POS \\
\hline $2-38$ & POS & POS & NEG & NEG & $\begin{array}{c}\text { POS } \\
(35.09)\end{array}$ & $\begin{array}{c}\text { POS } \\
(34.06)\end{array}$ & POS \\
\hline
\end{tabular}

415 reference test (after retest)

\begin{tabular}{cc||cc} 
& & \multicolumn{2}{c}{ PHE reference test } \\
& & POSITIVE & NEGATIVE \\
\hline SAMBA SARS-CoV-2 & POSITIVE & 90 & 0 \\
Test & NEGATIVE & 1 & 81
\end{tabular}

419 